Psychological and pedagogical problems of modern specialist formation

UDC 008 - 024.63:316.28]::316.772.2-045.7-04:376-054.62

DOI 10.26697/9789669726094.2017.57

Inna Zavaruieva

Dnipropetrovsk National University of Railway Transport

named after academician V. Lazaryan

\title{
INTERCULTURAL COMMUNICATION AND THE USE OF NON-VERBAL MEANS IN THE LEARNING FOREIGN
}

The article considers the problem of using non-verbal components in the teaching of Russian as a foreign language, analyzes the features of nonverbal means of communication serving to create, transmit, and perceive messages in intercultural communication. The study and teaching of a foreign language should be carried out in close connection with the world of the native speakers, in an inseparable unity with the cultures of peoples who use these languages as a means of communication. In the process of communication, an important role belongs to the culture of communication, to which not only the form of speech relates, but also its non-verbal component (body movements, mimics, gestures, etc.). Non-verbal components are essential components of communication, since they are the most important bearers of message values. An important contribution to the problem of studying non-verbal communication was made by the domestic and foreign scholars A. Piz, M. Kozzolino, T. M. Nikolaev, B. A. Uspensky, $V$. P. Morozov. The importance of teaching methods for RCTs is a problem related to the study of the linguistic and conceptual picture of the world of the Russian person, knowledge through the language of axiology, the emotional and ethical spheres of Russians. All this makes it possible to get closer to the understanding of the Russian people, promote more successful intercultural communication, and form a special attitude towards the culture of the country of the language under study.

Keywords: nonverbal communication, communication culture, language and conceptual picture of the world, the semantics of non-verbal communication.

\section{Introduction}

One of the urgent problems in the teaching of a foreign language today is the need for a deeper study of the world of its carriers. Without understanding socio-economic systems, knowledge of cultures, studying traditions that have shaped the way of thinking of those people with whom it is necessary to interact, it is impossible to learn the language as a means of communication. In modern linguistics, culturology, in the methodology 
of teaching foreign languages, intercultural communication is the object of close attention of scientists.

The pages of the scientific literature pay great attention to the problem of intercultural communication in professional and pedagogical activity. One of the aspects of this direction is the study of non-verbal means of communication, which plays an important role in the process of intercultural interaction, since it is known that various means of non-verbal communication (gesture, facial expression, posture, view, distance) are in some cases more expressive and effective than words. In modern linguistics, culturology, the methodology of teaching foreign languages, intercultural communication is the object of close attention of scientists. Among the works in the field of cultural communication are the works of Vereshchagin E. M., Ignatova I. B., Kostomarov V. G., Mitrofanova O. D., Furmanova V. P., Bakhtina M. M., Ter-Minasova S. G., Afanasyeva I. N., Busygina A. G., Busygina A. L., Grekova A. A. and others.

According to me Ter-Minasova S. G., the basis of any communication is the "mutual code», mutual knowledge of the realities, knowledge of the subject of communication between the participants in communication [5], so the study and teaching of a foreign language should be carried out in close connection with the world of the speakers of the language being studied, in indissoluble unity with cultures of peoples using these languages as a means of communication. Only in this way it is possible to provide foreign language learners with the necessary background knowledge, without it, real communication is impossible. In every country, people communicate in different ways: in accordance with their customs, traditions and mentality. In the process of communication, an important role belongs to a culture of communication, which includes not only the forms of speech, but also its non-verbal component (body movements, facial expressions, gestures, etc.). Non-verbal components are the most important components of communication, since they are the most important carriers of message values. Most often the non-verbal transmission occurs simultaneously with the verbal and can either enhance or change the content of words. In the opinion of psychologists, $60-80 \%$ of communication occurs due to non-verbal means only $20-40 \%$ - due to verbal ones. This opinion is confirmed by researches of scientists in the field of cultural communication, according to the data presented in the book of Ter-Minasova's S. G. «War and the World of Languages and Cultures», communication consists of: $7 \%$ verbal means proper, $38 \%$ phonetic language design, $55 \%$ non-verbal means [4, p. 93].

A significant contribution to the problem of studying non-verbal communication was made by domestic and foreign scientists Pease A., Koztsolino M., Nikolaeva T. M., Uspensky B. A., Morozov V. P. 


\section{Psychological and pedagogical problems of modern specialist formation}

The relevance of the topic of this work is conditioned by the needs of the communicative and activity-based methodology of teaching Russian as a foreign language. The aim of the study is to comprehensively interpret the non-verbal means of communication. Importance for the methodology of teaching RCTs presents problems related to the study of the linguistic and conceptual picture of the world of the Russian people, cognition through the language of axiology, the emotional and ethical spheres of Russians. All this allows us to approach the understanding of the Russian people, contributes to a more successful intercultural communication, and forms a special attitude to the culture of the country of the studied language.

\section{Materials and methods}

A foreign student who for the first time found himself in a new socio-cultural environment without knowing the language can instinctively (at the level of gestures and facial expressions) perceive certain information. Often, facial expressions or gestures affect the addressee more than any words - induce to action or, conversely, to relaxation. The gesture reports what is between the lines and makes communication more complete and vivid.

One of the most important qualities of a teacher is his ability to organize interaction with students. Not only verbally, but also with nonverbal means. When organizing the teaching of the Russian language for foreign students, it is necessary to take into account that speech gestures are nationally and socially conditioned: different gestures used to express one feeling, and the same movement of the hand can mean different things in different peoples - from anger to amazement; A gesture adopted in a particular social environment can cause condemnation or misunderstanding in other collectives. Accounting for this factor is important for the proper organization of the teacher's communication with foreign students, and is also an integral component of mastering Russian language by foreign students. Thus, in order to avoid misunderstandings in parallel with other aspects of the Russian language, it is necessary to acquaint foreign students with the typical gestures and facial gestures. When the national-cultural component is included in the content of teaching a foreign language, adequate means are needed to assimilate it. Such means can be, first of all, authentic materials: literary and musical works, objects of real reality and their illustrative images, which are the most likely to bring the student closer to a natural and cultural environment. There is no doubt that the wordless language of the posture, gesture, look, spatial composition of the pictorial canvas and the film frame has not been sufficiently studied. Thanks to researches in the field of semiotics, sociolinguistics and the theory of communication. The questions of studying sign language attract the attention of scientists. Of course, the teacher of Russian as a foreign 
language should take into account that there are national differences in the use of gestures. In a foreign audience, it is especially important to understand the teacher's gestures used by students, and to use non-verbal means by the teacher, adequately perceived by the audience.

With inter ethnic communication, questions of semantics gesture become especially important. Errors in interpretation occur mainly when they coincide formally: a similar gesture is given to the meaning that it has in its culture (the textbook example of misinterpretation with formal gesture coincidence is the opposite movement of the head in the affirmation and denial of Russians and Bulgarians, in the German and Ukrainian communicative Behavior. There is a difference when the German begins to count, then the bent fingers of the left hand unbend with the fingers of the right hand, starting with the thumb, we have the opposite, the fingers bend with a little finger). The teacher should also remember that foreign communicative behavior has gestures that are absent in the native language (for example, a gesture of tapping the table with bones of the fingers, expressing approval and satisfaction from a well-read lecture or report at the conference). Shallow penetration into the environment of the studied language leads to errors and comic situations. There are general norms of gesticulation adopted by different peoples (from the reserved to the temperamental in the north), some specific differences in the sign language have social, professional and confessional groups. All these facts should be taken into account by teachers in the classroom. Knowledge of foreign language students' dictionaries will allow the teacher to receive feedback when submitting material and to correct the information provided during the course. But, nevertheless, not knowing the language of another country, he can explain himself with foreign students using gestures. Hence, there are some general rules for their application and decoding everyone, for example, understands that a raised hand means calling for attention, clapping hands - approval, nodding his head - consent threatening to shake his fist - anger, shrugging his shoulders - lack of interest, passivity, yawn boredom, hand motion palm to himself - request to approach, etc.

Because of insufficient knowledge of vocabulary, foreign students who first find themselves in a new social environment experience feelings of anxiety and anxiety associated with a number of psychological reasons they always cannot tell the teacher. The gestures are more eloquent than their words. You just need to be able to notice the signals that are sent. An attentive teacher in the gesticulation of students can determine their emotional state. Each emotion has a special effect on body movements, slowing or speeding them up. For example, joy, high spirits make the movements quick, expansive, rhythmic, expressive. On the contrary, with depression the person's movements become slow, indecisive, and an attack 


\section{Psychological and pedagogical problems of modern specialist formation}

of anger manifests itself in a delay in breathing and closing of the lips. Various ways can also be expressed discontent, vexation or disgust. The presence of such gestures and body movements in the student testifies the appearance of psychological barriers before him.

The Incorrect interpretation of completely harmless gestures sometimes leads to sad misunderstandings. Teachers of Russian as a foreign language need to take this into account and develop their own specific strategy and tactics that will help to remove psychological difficulties, create conditions under which students will feel psychologically comfortable in a foreign culture environment. The knowledge of culturallyconditioned behavioral scenarios (the norm that native speakers of a particular culture usually follow in communication) makes it possible to decipher what they see, hear and helps to understand others as well [1]. In the absence of non-verbal means of communication, the communication process proves to be inadequate.

\section{Discussion and conclusions}

Thus, it should be said that non-verbal communication is of great importance in cross-cultural relations. Studying a foreign language is necessary to teach its silent options. Reading correctly the body language and using it in communication between representatives of different cultures can be successful and fruitful. The linguistic-cultural aspect in the study of a foreign language provides with the allocation of linguistic units, signs that have features of verbal and non-verbal design in the native and studied language. Ethical norms of communication that reflect the mentality of this cultural and linguistic community, to allow the statement to be adequately addressed to a specific situation. And then the understanding will be everywhere: in the streets of London, and in the Middle and Far East.

So, using non-verbal means of communication, the teacher raises the effectiveness of the learning process, creates a positive tone of communication, establishes and maintains contact, affects the verbal activity of students and promotes the memorization of educational material as well.

\section{References}

1. Vezhbitckaia, A. (1996). Jazyk. Kultura. Poznanie [Language. Culture. Cognition]. Moscow: Russkie slovari. (in Russian)

2. Morozov, V. P. (1998). Iskusstvo $i$ nauka obshhenija: neverbal'naja kommunikacija [The art and science of communication: nonverbal communication]. Moscow: IPRAN. (in Russian)

3. Nikolaeva, T. M., \& Uspenskij, B. A. (1966). Jazykoznanie i paralingvistika [Linguistics and Paralinguistics]. In T. M. Nikolaeva (Ed.), Lingvisticheskie issledovanija po obshhej i slavjanskoj tipologii - Linguistic 
researches on the general and Slavic typology (pp. 63-65). Moscow: Nauka. (in Russian)

4. Piz, A. (1995). Jazyk zhestov: kak chitat' mysli drugih ljudej po ih zhestam [Sign language: how to read other people's thoughts by their gestures]. Moscow: Aj-K'ju. (in Russian)

5. Ter-Minasova, S. G. (2007) Vojna i mir jazykov i kul'tur [War and the world of languages and cultures]. Moscow: AST, Astrel', Hranitel'. (in Russian)

6. Ter-Minasova, S. G. (2000). Jazyk i mezhkul'turnaja kommunikacija [Language and intercultural communication]. Moscow: Slovo. (in Russian)

Інна Заварусва. Міжкультурна комунікація і використання невербальних засобів в процесі навчання іноземних студентів.

У статті досліджується проблема використання невербальних компонентів під час викладання російської мови як іноземної, аналізуються особливості невербальних засобів комунікащії, ще служать для створення, передачі і сприйняття інформації в прочесі міжкультурної комунікації. Вивчення $і$ викладання іноземної мови повинно здійснюватися в тісному зв'язку зі світом носїв мови, яку вивчають, в нерозривній єдності з культурами народів, щяо використовують иі мови як засіб спілкування. У прочесі спілкування важлива роль належить культурі спілкування, до якої відноситься не тільки форма мови, а і ї̈ невербальна складова (рухи тіла, міміка, жести $i$ m.n.). Невербальні компоненти є значними складовими комунікації, оскільки саме вони виступають найважливішими носіями значень повідомлення. Істотний внесок в проблему вивчення особливостей невербального спілкування внесли вітчизняні та зарубіжні вчені А. Піз, М. Кочуоліно, Т. М. Ніколаєва, Б. А. Успенський, В. П. Морозов та інші. Ключовими для методики викладання російської мови як іноземної $\epsilon$ проблеми, пов'язані з вивченням мовної та концептуальної картини світу людини, пізнанням через мову аксіології, емоційної і етичної сфер росіян. Все це дозволяє наблизитися до розуміння народу, сприяє більш успішній міжкультурній комунікації, формує особливе ставлення до культури країни мови, щуо вивчають.

Ключові слова: невербальні засоби комунікації, комунікачія культур, мовна і концептуальна картина світу. 


\section{Psychological and pedagogical problems of modern specialist formation}

Inna Zavaruieva. Międzykulturowa komunikacja i użycie niewerbalnych środków $w$ trakcie nauczania studentów obcokrajowców.

W podanym artykule rozpatruje się problem wykorzystywania komponentów niewerbalnych w nauczaniu języka rosyjskiego jako języka obcego. Oprócz tego analizie poddane sa właściwości niewerbalnych środków komunikacji, stużacych do tworzenia, przekazywania oraz odbierania wiadomości $w$ komunikacji międzykulturowej. Nauka i nauczanie języka obcego powinny odbywać się w ścistym zwiazku ze światem mediów badanego języka, w nierozerwalnej taczności z kultura narodów wykorzystujących języki jako narzędzia komunikacji. W procesie komunikowania się znaczaca role odgrywa kultura komunikacji, do której odnosi się nie tylko forma wypowiedzi, ale $i$ jej niewerbalne składniki (gesty, mimika itp.). Niewerbalne środki sq najważniejszymi elementami komunikacji, ponieważ to one stanowiq najistotniejsze nośniki wiadomości. Znaczacy wkład $w$ problematykę nauki komunikacji niewerbalnej wnieśli krajowi i zagraniczni naukowcy: A. Pease, M. Koccolino, T. M. Nikotajew, B. A. Uspienski, W. P. Mrozów. Ważne dla metodyki nauczania języka rosyjskiego jako języka obcego sa kwestie zwiazane z nauka języka oraz pojęciowy obraz świata rosyjskiego człowieka, poznanie przez język aksjologii emocjonalnej $i$ etycznej sfer rosyjskich. Wszystko to pozwala zbliżć się do zrozumienia narodu, przyczynia się do skuteczniejszej komunikacji międzykulturowej, tworzy szczególny stosunek do kultury kraju badanego języka.

Slowa kluczowe: niewerbalne środki komunikacji, komunikacja kultur, językowy i konceptualny obraz świata.

Received 05.07.2017

\section{Information about the author:}

Zavaruieva Inna - Doctor of Philosophy in Philology, Associate Professor at the Department of Humanitarian Disciplines for Foreign Students, Dnipropetrovsk National University Of Railway Transport named after academician V. Lazaryan. 